\title{
RANCANG BANGUN GAME 3D PAHLAWAN NASIONAL INDONESIA GENRE PAIRS GAME MENGGUNAKAN METODE FISHER YATES
}

\author{
Afif Syarifudin $\mathbf{M}^{(1}$, Fresy Nugroho, M.T. ${ }^{2}$ \\ ${ }^{(1,2}$ Jurusan Teknik Informatika \\ UIN Maulana Malik Ibrahim Malang \\ afifmudin07@gmail.com
}

\begin{abstract}
ABSTRAK
Pairs Game merupakan salah satu permainan yang cukup sederhana baik dari segi aturan mau pun cara bermainnya, cukup mencocokkan atau menghubungkan sesuatu yang sama atau saling berkaitan. Pada penelitian ini, pairs game yang dibuat menggunakan atribut Pahlawan Nasional Indonesia sebagai media permainan, di mana aturan permainannya adalah pemain di wajibkan untuk mencocokkan gambar-gambar Pahlawan Nasional Indonesia untuk mendapatkan seputar informasi dari pahlawan terkait gambar yang sudah dicocokkan. Penelitian ini bertujuan membangun pairs game berbentuk 3D dengan konten gambar pahlawan Indonesia berbasis web serta menerapkan metode fisher yates sebagai pengacak pasangan gambar.
\end{abstract}

Kata Kunci: PairsGame 3D, Pahlawan Nasional Indonesia, Fisher Yates

\section{LATAR BELAKANG}

Indonesia merupakan salah satu negara yang mempunyai banyak sejarah. Apalagi terkait proses memerdekakan diri dari para penjajah maupun konflik internal yang pernah terjadi di dalamnya. Pada setiap kejadian tersebut tentu ada sosok yang berjuang untuk menyelesaikan dari setiap masalah yang ada. Sosok seperti ini patut disebut sebagai pahlawan, karena perannya yang begitu vital dalam penyelesaian masalah yang dihadapi Indonesia. Selain itu keberadaan mereka patutlah untuk dikenang, diabadikan dan di contoh oleh setiap warga Indonesia.

Pada penelitian ini, sosok pahlawan yang dijadikan atribut tidaklah semua pahlawan yang berjuang untuk menyelesaikan masalah yang pernah dihadapi Indonesia, namun hanya sebagian besar yang mewakili dan yang di nobatkan sebagai Pahlawan Nasional Indonesia. Selain itu juga pada penelitian ini atribut pahlawan yang digunakan berbentuk gambar bukan action figure, sehingga pada penelitian ini mengambil konsep pairs game.

Pairs game merupakan permainan yang mencocokkan atau mengaitkan sesuatu yang sama atau terkait. Selain itu jenis game ini merupakan jenis game yang cukup ringan untuk dimainkan oleh setiap orang, baik yang hobi atau pemula terhadap game.

Pada dasarnya pairs game kebanyakan mempunyai visual 2D (dimensi), namun pada penelitian ini mencoba mengubahnya ke bentuk visual 3D yang merujuk pada pairs game uji coba yang dibuat oleh Paul Hayes yang tertulis di artikelnya "Adding touch gestures and mouse Control do a 3D CSS cabe". Namun pada penelitian tersebut tidak ditanamkannya metode tertentu, semisal dalam pengacakannya, di mana pada gametersebut pengacakan bersifat mengacak relatif dalam artisan, jika di kembangkan maka game yang dibuat meski harus melewati level- level tertentu untuk mendapatkan pengacakan data lainnya. Namun pada penelitian ini game di buat tidak harus melewati level tertentu untuk mencapai mencapai tujuan khususnya sehingga pemain dengan mudah mendapatkan hasil tampilkan dari pengacakan data secara keseluruhan.

Banyak metode pengacakan yang dapat digunakan untuk memproses pengacakan, namun pada penelitian ini, peneliti mencoba memasukan metode fisher yates sebagai metode pengacakannya yang merujuk pada game sejenis yang di buat oleh Christopher James Willcock yang berjudul Concentration [1\&5].

Berdasarkan kondisi di atas peneliti mencoba mengembangkan game 3D Pahlawan Nasional Indonesia bergenre pairs game yang menggunakan metode fisheryates sebagai pembangkit permainan.

\section{PERANCANGAN SISTEM}

Pada gambar 1 merupakan proses alur dari pairsgame 3D Pahlawan Nasional Indonesia dengan aturan, jika pemain ingin mengetahui informasi seputar pahlawan yang ada di gambar, maka pemain harus mencocokkan gambar yang sama, sedangkan untuk metode pengacakannya diterapkan saat sistem mengambil data dan meletakkan gambar di posisi secara acak berdasarkan level, namun penggunaan level pada game hanya menentukan jumlah data gambar yang dijadikan output.

\section{PENERAPAN METODE}

Metode pengacakan fisher yates merupakan metode yang juga biasanya digunakan pada permainan berjenis puzzle salah satunya pairs game[2,3,4]. Berikut adalah psuedocode dari metode tersebut: 


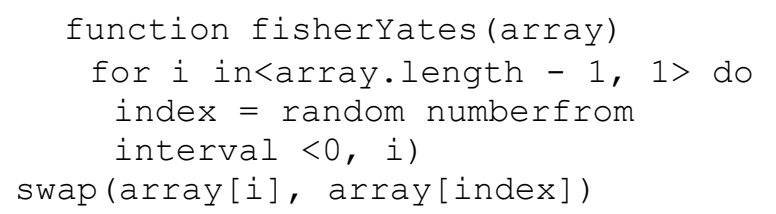

Pada penelitian ini pembuatan game dikembangkan dengan basis web. Dalam perkembangannya, untuk memasukan fungsi-fungsi tersebut dapat dilakukan dengan dua cara, memasukkan fungsi tersebut pada pemrograman web yang bersifat server side seperti PHP atau yang bersifat client side seperti javascript. Namun pada penelitian ini fungsi tersebut dimasukkan ke pemrograman web yang bersifat client side dengan pertimbangan dapat di jalankan secara offline maupun online, akan tetapi jika menggunakan pemrograman yang bersifat server side maka dibutuhkan local host untuk menjalankannya secara offline, sehingga peneliti memasukan fungsi tersebut pada Javascript, berikut adalah source code dari metode fisher yates jika dimasukkan ke javascript.

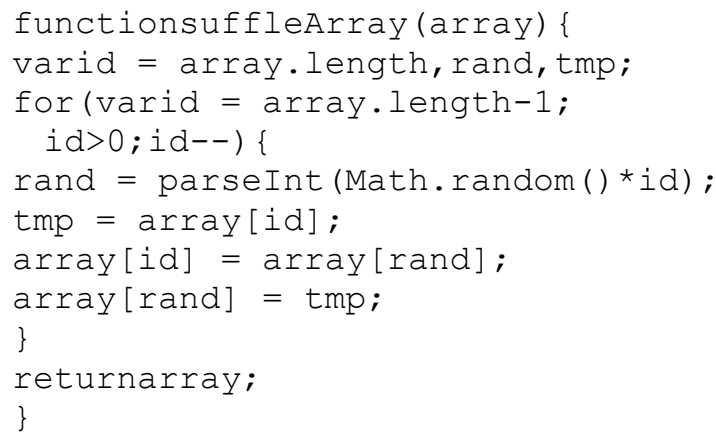

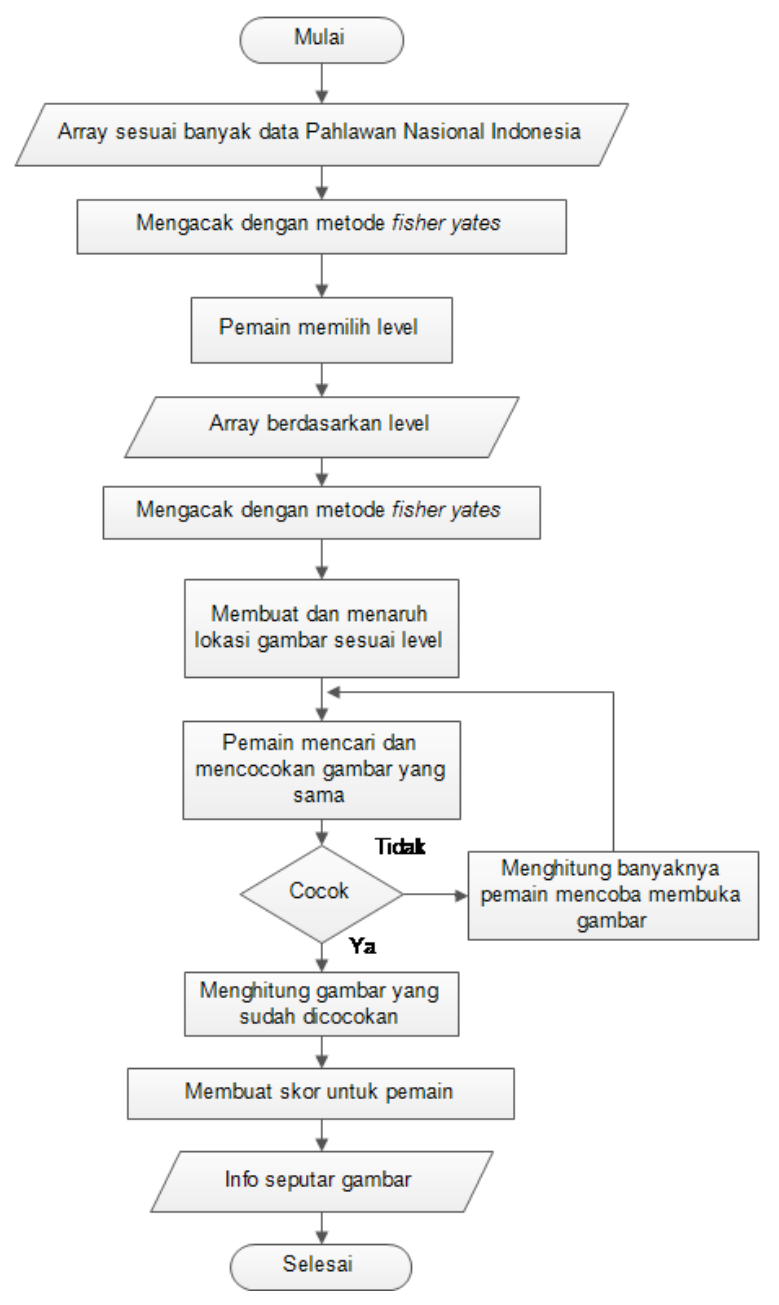

Gambar 1 Proses Alur Permainan

\section{Hasil Perancangan dan Pengujian}

Pada gambar 2 merupakan gambar antarmuka awal dari game yang berisi slide petunjuk permainan pairs game 3D Pahlawan Nasional Indonesia. Gambar 3 adalah antarmuka saat pemain memilih level, di mana setiap levelnya mempunyai kondisi yang berbeda-beda, jika level mudah maka antarmuka berbentuk seperti gambar 4, level sedang antarmuka seperti gambar 5 dan level sulit antarmuka seperti gambar 6. Pada masingmasing level data yang di tampilkan beda-beda. Level mudah jumlah data sebanyak 12 gambar (total gambar 24 karena setiap gambar mempunyai pasangan), level sedang jumlah datanya 54 gambar dan level sulit sebanyak 96 gambar.

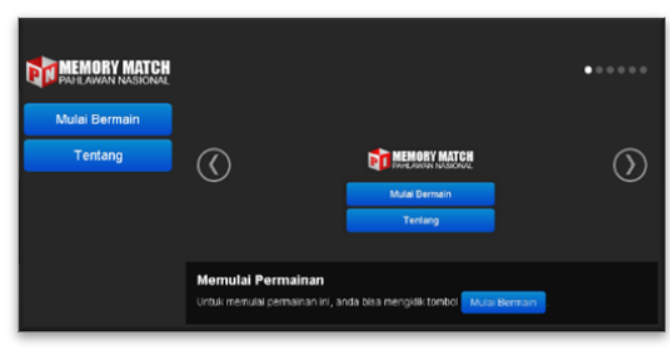

Gambar 2 Antarmuka awal game 


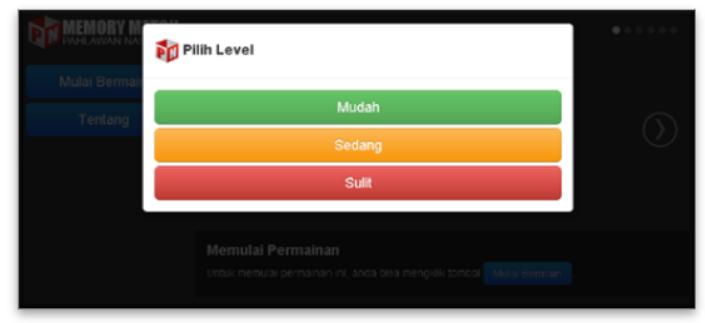

Gambar 3 Antarmuka saat memilih level

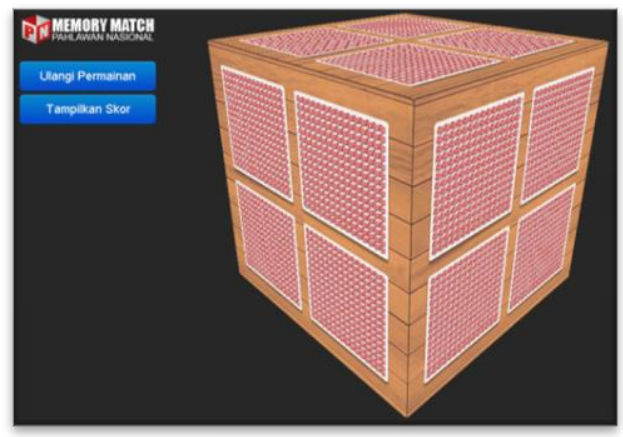

Gambar 4 Antarmuka saat level mudah

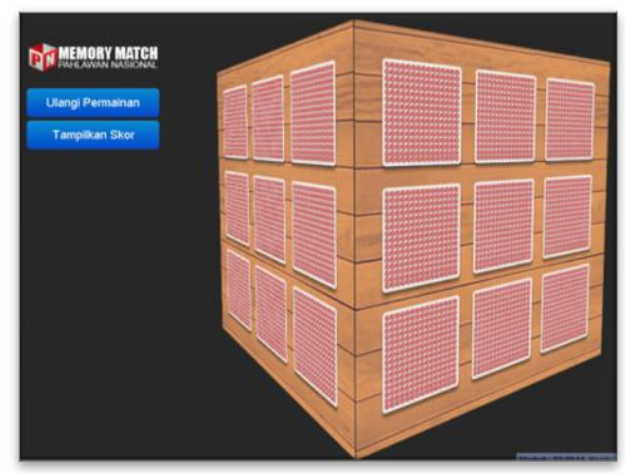

Gambar 5 Antarmuka saat level sedang

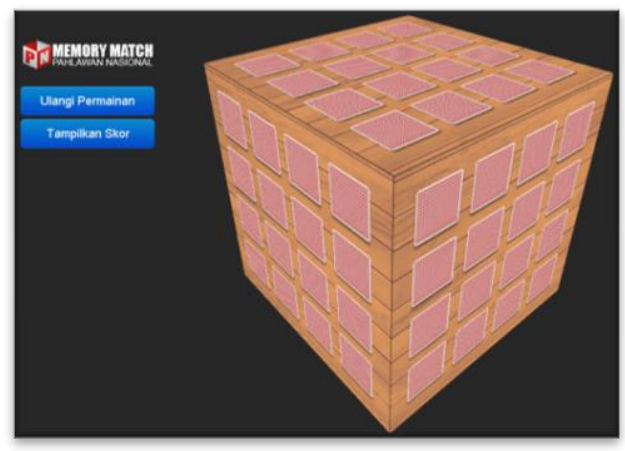

Gambar 6 Antarmuka saat level sulit

\section{Pengujian sistem game}

Uji coba pada pairs game PNI (Pahlawan Nasional Indonesia) dilakukan dengan cara mencoba memainkannya sebanyak 10x setiap levelnya, namun pada level sedang terdapat dua kali error pada game yang mengakibatkan kartu atau gambar yang muncul tak beraturan seperti gambar 7 :

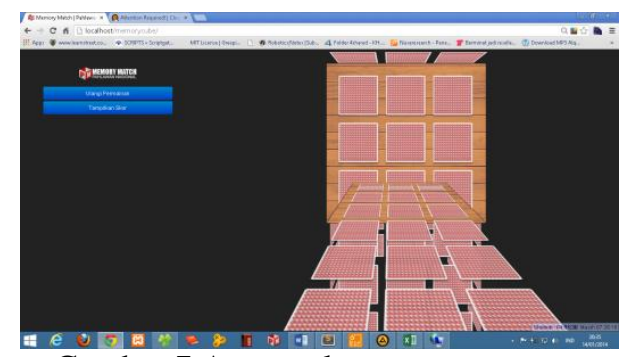

Gambar 7 Antarmuka saat game error

akan tetapi setelah di uji coba ulang, ternyata kesalahan yang didapatkan dikarenakan mouse pointer yang digunakan peneliti mengalami kerusakan saat mengklik kanan mouse. Namun tidak menutup kemungkinan jika kondisi error ada disebabkan struktur pengodean daripada game yang dibuat kurang sempurna.

\section{Pengujian pada Browser yang berbeda}

Pada uji coba lainnya, peneliti menguji pairs game PNI terhadap penggunaan browser dikarenakan game yang dibuat berbasis web, hal tersebut dilakukan juga dikarenakan agar mengetahui macam-macam browser yang support untuk pairs game PNI. Berikut diperlihatkan hasil penerapan browser berbeda pada game hasil perancangan.

\section{- $\quad$ Safari 5.17}

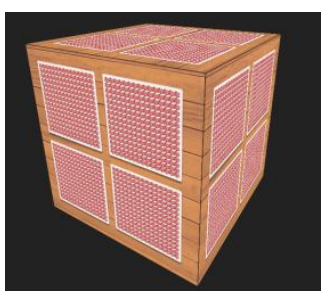

Gambar 8 Visual 3D pada browser Safari

Dari 5 jenis browser yang diuji cobakan, hanya 3 yang menampilkan visual 3D dengan baik, namun saat digerakkan hanya Opera dan Chrome yang berjalan dengan baik. Hal tersebut dikarenakan Safari yang digunakan versi lama, sehingga tidak menutup kemungkinan jika menggunakan versi yang terbaru bisa berjalan dengan baik seperti halnya pada Chrome dan Opera.

- Opera 18.0.1284.68

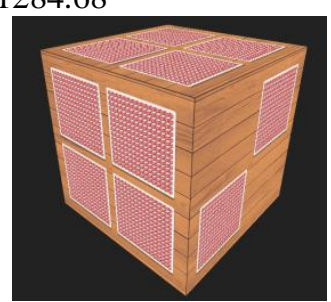

Gambar 9 Visual 3D pada browser Opera

- Chrome31.0.1650.63 


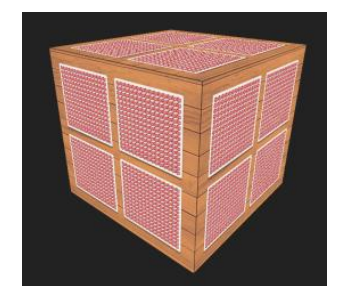

Gambar 10 Visual 3D pada browser Chrome

- $\quad$ Firefox 26.0

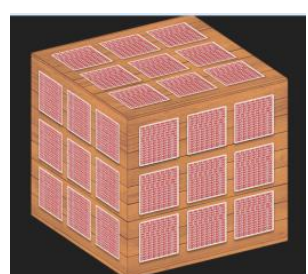

Gambar 11 Visual 3D pada browser Firefox

- $\quad$ Internet Explorer 10.0.9200.16750 1

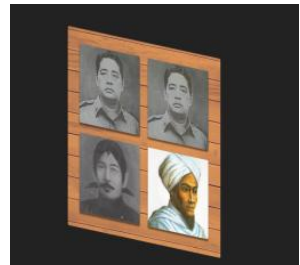

Gambar 12 Visual 3D pada browser IE

\section{KESIMPULAN}

Pairs game PNI dapat berjalan dengan ditambahkannya metode fisher yates sebagai pembangkit permainannya, akan tetapi masih terdapat banyak kekurangan pada game ini seperti belum responsive (dapat menyesuaikan pada resolusi layar), hanya dapat berjalan dengan baik pada browser Chrome dan Opera.

\section{REFERENSI:}

[1]Ibijola,Ade; Olu,Abejide (2012), "A Simulated Enhancement of Fisher-Yates Algorithm for Shuffling Virtual Card Games Using DomainSpecific Data Structures", International Journal of Computer Application, Volume 54-N0.11, September 2012.

[2]Louchard,G;Prodinger,H;Wagner,S， (2007) ,"Joint Distributions for Movements of Elements In Sattolo's and The Fisher-Yates Algortihm".

[3]Stefanescu,C;Berger,VW.;Hershberger,S, (2003), "Yates's Continuity Correction".

[4]Ali,Asghar (2004) , "Automorphism Group Generators for Fisher and Yates 6X6 Reduced Latin Squares and Their Equivalence With Schonhardt's Species", Journal of Research (Science), Bahauddin Zakariya University, Multan, Pakistan. Vol.15, No.1, June 2004, pp.7377

[5]Bonnecaze,Alexis;Liardet,Pierre;(2012),"Uniform Generators and Combinatorial Designs" 